\section{REFERENCES AND NOTES}

1. Allen, R. A., and Baggenstoss, A. H.: The pathogenesis of fibrocystic disease of the pancreas. Amer. J. Pathol., 31: 337 (1955).

2. Blanc, W. A.: Pathology of the pancreas and gastrointestinal tract. "GAP" Conference Reports, June 1972, National Cystic Fibrosis Research Foundation, Atlanta, Ga.

3. Bloomfield, J., Dascalu, J., VanLennep, E. W., and Brown, J.: Hypersecretion of zymogen granules in the pathogenesis of cystic fibrosis. Gut, 14: 558 (1973).

4. Busch, H.: Biochemical aspects of pancreatitis. Yale J. Biol. Med., 29: 596 (1957).

5. Chernick, W. S., and Barbero, G. J.: Studies on human tracheobronchial and submaxillary secretions in normal and pathophysiological conditions. Ann. N. Y. Acad. Sci., 106: 698 (1963).

6. di Sant'Agnese, P. A., and Talamo, R. C.: Pathogenesis and pathophysiology of cystic fibrosis of the pancreas. N. Engl. J. Med., 277: 1287 (1967).

7. Donnison, A. B., Shwachman, H., and Gross, R. E.: A review of 164 children with meconium ileus. Pediatrics, 37: 833 (1966).

8. Forstner, J. F., Jabbal, I., and Forstner, F. F.: Interaction of calcium with intestinal goblet cells. Clin. Res., 21: 1033 (1973).

9. Hadorn, B., Johansen, P. G., and Anderson, C. M.: Pancreozymin secretin tests of pancreatic function in cystic fibrosis and the significance of the results for the pathogenesis of the disease. Can. Med. Ass. J., 98: 377 (1968).

10. Hsu, J. M.: Pancreatic carboxypeptidases: Activities in zinc-deficient rats Science, 153: 882 (1966)

11. Kleiner, I. S., and Orten, J. M.: Biochemistry, p. 268 (C. V. Mosby, St. Louis, 1962).

12. Kopito, L.: Atomic Absorption Spectroscopy in Clinical Chemistry, Vol. II
(Fisher Scientific Co., Pittsburth, 1970).

13. Kopito, L., and Shwachman, H.: Mineral composition of meconium. J. Pediat., 68: 313 (1966)

14. Kopito, L, E., Kosasky, H. J., and Shwachman, H.: Water and electrolytes in cervical mucus from patients with cystic fibrosis. Fertil. Steril., 24: 512 (1973).

15. Rasmussen, H.: Cell communication, calcium ion, and cyclic adenosine monophosphate. Science, 107: 404 (1970).

16. Rule, A. H., Kopito, L. E., and Shwachman, H.: Chemical analysis of ejaculates from patients with cystic fibrosis. Fertil. Steril., 21: 515 (1970).

17. Shwachman, H., Dooley, R. R., Guilmette, F., Patterson, P. R., Weil, C., and Leubner, H.: Cystic fibrosis of the pancreas with varying degrees of pancreatic insufficiency. J. Dis. Child., 92: 347 (1956).

18. Shwachman, H., and Grand, R.: Cystic fibrosis. In: M. Slesinger and J. Fordtran: Gastrointestinal Diseases; Pathophysiology, Diagnosis and Management. (Saunders, Philadelphis, 1973).

19. Ting Kai Li: The functional role of zinc in metalloenzymes. In: A. S. Prasad: Zinc Metabolism, p. 48 (Charles C. Thomas, Springfield, Ill., 1966).

20. Vallee, B. L. Zinc and metalloenzymes, In: M. L. Anson, K. Bailey, and J. T. Edsall: Advances in Protein Chemistry, Vol. 10, p. 318 (Academic Press, New York, 1955).

21. The present address of Dr. L. E. Kopito is: Department of Nutrition, Massachusetts Institute of Technology, Cambridge, Mass.

22. The present address of Dr. J. Edlow is: Department of Pathology, Mt. Sinai Hospital, New York, N. Y.

23. Requests for reprints should be addressed to: H. Shwachman. The Children's Hospital, Medical Center, Boston, Mass. 02115 (USA).

24. Accepted for publication March 3, 1976
Calcitonin parathyroid hormone calcium phosphorus, inorganic magnesium plasma newborn

\title{
Calcium Metabolism in Newborn Animals: The Interrelationship of Calcium, Magnesium, and Inorganic Phosphorus in Newborn Rats, Foals, Lambs, and Calves
}

\author{
JEAN-MICHEL GAREL ${ }^{(48)}$ AND JEAN-PIERRE BARLET \\ Laboratoire de Physiologie du Developpement, Université Pierre et Marie Curie, Paris, and Physiopathologie de la \\ Nutrition, I.N.R.A. Theix, Beaumont, France
}

\section{Extract}

The plasma concentrations of calcium, inorganic phosphorus, and magnesium were studied during the early postnatal period in a rodent (rats), in ruminants (lambs and calves), and in foals. Decreases in plasma calcium after birth were observed only in newborn rats and foals. In rats the postnatal fall in plasma calcium level was already evident $1 \mathrm{hr}$ after cesarean section $(9.20 \mathrm{mg} / 100$ $\mathrm{ml}$ ) as opposed to $11.90 \mathrm{mg} / 100 \mathrm{ml}$ in utero) and reached a nadir within $6 \mathrm{hr}(-4.05 \mathrm{mg} / 100 \mathrm{ml})$. Newborn foals showed a small decrease in plasma calcium $(-0.73 \mathrm{mg} / 100 \mathrm{ml}) 48 \mathrm{hr}$ after birth. In the four species, plasma inorganic phosphorus increased in the days after birth; plasma magnesium levels were only slightly affected over the first week of life. In ruminants and in foals, the high plasma calcitonin levels were not always related to plasma calcium, nor with plasma inorganic phosphorus over the first week of life. Newborn calves showed at birth detectable levels of plasma parathyroid hormone, similar to those found in their mothers, with individual values ranging from $0.80-3.50 \mathrm{ng} / \mathrm{ml}$. These re- sults are discussed in light of the well known early neonatal hypocalcemia occurring in normal human newborns.

\section{Speculation}

The parathyroid status at birth is species dependent. In some species, it has been suggested that in utero, high plasma calcium levels inhibit the parathyroid function before birth, but other unknown factors may be involved in this suppression. The maturity of the renal cortex adenyl cyclase activity in the early postnatal period is also species dependent and the degree of renal immaturity is not sufficient to explain the postnatal increase in plasma inorganic phosphorus.

Hypocalcemia is well known to occur in human neonates but is strangely unreported in animals. It has been postulated that hyperphosphatemia per se, transient hypoparathyroidism, and/or endorgan unresponsiveness might explain the early postnatal de- 
crease in plasma calcium. Craig and Buchanan (13) stated that hypocalcemic tetany per se occurring within $36 \mathrm{hr}$ after birth in human neonates should be regarded as an exaggeration of a normal physiologic state. The studies of plasma calcium levels in maternal and fetal blood $(7,14,15,40)$ suggested the presence of active transport across the placenta. The sudden cessation of this source of calcium may contribute to the development of neonatal hypocalcemia. In the first 2 days of extrauterine life, the serum calcium in full term newborns physiologically decreases to levels between 8 and $9 \mathrm{mg} / 100 \mathrm{ml}$. A more pronounced postnatal decrease of the serum calcium is defined as a pathologic neonatal hypocalcemia.

İn newborn rats it has been shown that plasma calcium concentration decreased after birth $(18,34)$, but in the newborn of some ruminant species the plasma calcium level was not changed in the first few days after birth (5).

In the present paper we have studied the interrelations between plasma calcium, inorganic phosphorus, and magnesium in the newborns of different species to draw some indications about the etiology of physiologically early postnatal decrease in plasma calcium level.

\section{MATERIAL AND METHODS}

\section{ANIMALS}

Newborn rats from pregnant females of the Sherman strain were used. In our colony, delivery takes place after 22 days of gestation. Two kinds of newborns were studied. (I) Newborns were delivered by cesarean section at 21.5 days of gestation. These fasted newborns were kept in a Humidicrib at $37^{\circ}$ for $8 \mathrm{hr}(70 \%$ of relative humidity) and remained unfed during the whole experimental period; blood parameters were studied from 1-8 hr after birth. (2) Naturally delivered newborns were kept with their mother and were allowed to nurse naturally. These animals were studied from $12 \mathrm{hr}$ after birth over the first week of life.

Nine newborn foals staying with their dams were suckling maternal milk. They were born from 7-year-old Comtoise mares carrying their third or fourth pregnancy. Six newborn lambs were also included in this study, born from Charmoise ewes; they were allowed to nurse naturally. Three newborn calves from 5-year-old Jersey cows were also used.

\section{BLOOD SAMPLING}

Blood was drawn in newborn rats through an incision across the axillary vessels after careful cleaning of the axillary region. In newborns from other species blood was sampled by puncture of the external jugular vein. In samples intended for hormone assays blood was collected in heparinized polyethylene tubes cooled in ice water, and containing the anti-protease, Iniprol (46) to inhibit enzymatic breakdown of calcitonin and parathyroid hormone. After centrifugation at $4^{\circ}$, the plasma was frozen at $-20^{\circ}$ until hormone assays.

\section{BIOCHEMICAL ANALYSIS}

Plasma calcium and magnesium levels were measured by atomic absorption spectrophotometry (Perkin-Elmer 303). Plasma inorganic phosphorus was estimated colorimetrically (11).

Plasma calcitonin (CT) in foals, lambs, and calves was measured by radioimmunoassay using a porcine system already described in detail $(25,27)$. This system involved purified porcine CT labeled with ${ }^{131} \mathrm{I}$ according to the Chloramine-T method of Hunter and Greenwood (32) by the C.N.T.S. (Centre National de Transfusion Sanguine, Paris, France) and antibodies raised in guinea pigs against partially purified porcine CT. Plasma CT in lambs were measured using $\mathrm{GP}_{2}$ antiserum which has been shown highly specific for pure ovine CT and the results were expressed in nanograms of ovine CT per $\mathrm{ml}$ plasma (25). Plasma CT in newborn foals and calves was estimated using $\mathrm{GP} 2_{5}$ antiserum which cross-reacted with equine and bovine CT (27) and the results were expressed in nanograms equivalents of porcine CT per $\mathrm{ml}$ plasma. Incubations were done in an equilibrium system at $4^{\circ}$ for 6 days. Phase separation was performed using powdered hydrated magnesium silicates. The sensitivity of the assay was $100 \mathrm{pg}$ porcine $\mathrm{CT} / \mathrm{ml}$ of plasma.

Plasma parathyroid hormone (PTH) in newborn calves was estimated by radioimmunoassay (23). Pure 1-84 bovine PTH was labeled with ${ }^{125} \mathrm{I}$ or used as a standard. An antibody was raised in a goat against 1-84 bovine PTH which was shown directed to the carboxyterminal part $(35-84)$ of the molecule. The tubes were incubated in an equilibrium system for 6 days at $4^{\circ}$ and the separation of bound from free labeled hormone was carried out using plasma-coated charcoal. The sensitivity of this assay was 300 $\mathrm{pg} / \mathrm{ml}$ plasma,

\section{RESULTS}

\section{NEWBORN RATS}

Unfed newborns delivered by cesarean section showed a sharp decrease in plasma concentrations of calcium and inorganic phosphorus within $2 \mathrm{hr}$ after birth $(\Delta \mathrm{Ca}=-3.00 \mathrm{mg} / 100 \mathrm{ml}$; $\Delta \mathrm{PO}_{4}=-3.60 \mathrm{mg} / 100 \mathrm{ml}$ ). Maximal hypocalcemia was reached $6 \mathrm{hr}$ after birth whereas maximal hypophosphatemia was apparent $4 \mathrm{hr}$ after birth. The plasma calcium level increased significantly 8 hr after birth in the fasted newborns (Fig. 1) and the plasma inorganic phosphorus level was increased $6 \mathrm{hr}$ after birth in the same animals (Fig. 1). Suckled newborn rats have low concentrations of calcium and inorganic phosphorus $12 \mathrm{hr}$ after birth but reached stabilized levels $36 \mathrm{hr}$ postpartum (Fig. 1). A slight decrease in the plasma magnesium level was observed in newborns delivered by cesarean section; 12-hr-old suckled newborns exhibited an increase in the plasma magnesium level, and over the first week of life the plasma magnesium concentration remained stable (Fig. 1).

\section{NEWBORN FOALS}

At birth the plasma calcium level was greater in the newborn than in the mother $(12.20 \pm 0.19$ vs. $11.54 \pm 0.21 \mathrm{mg} / 100 \mathrm{ml}$; $P<0.05)$. A slight hypocalcemia $(-0.73 \mathrm{mg} / 100 \mathrm{ml} ; P<0.025$ occurred in the $48 \mathrm{hr}$ after birth (Fig. 2); thus maternal and newborn levels were not different. In 7-day-old newborn foals the plasma calcium level was also greater than in the mothers. The plasma inorganic phosphorus concentration in the 0-day-old newborn was greater than in the mother $(4.47 \pm 0.21$ as opposed to $2.39 \pm 0.28 \mathrm{mg} / 100 \mathrm{ml} ; P<0.001)$ and this level increased

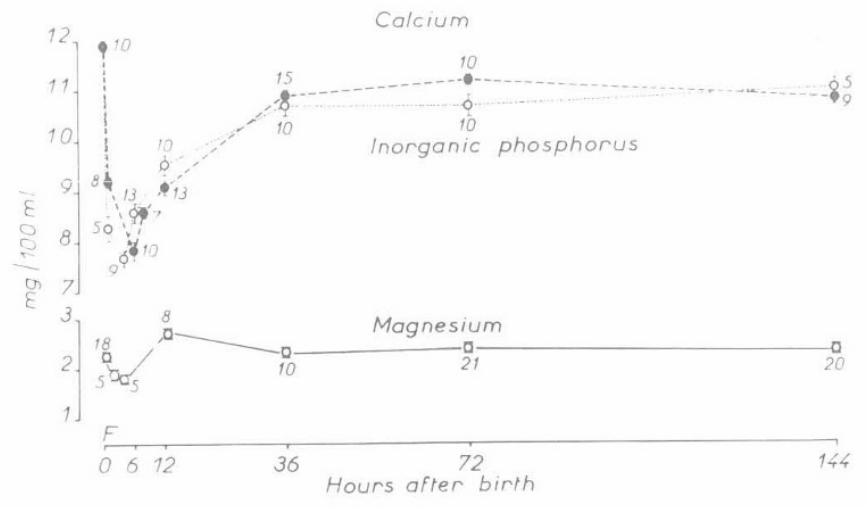

Fig. 1. Plasma concentrations of calcium, inorganic phosphorus, and magnesium in newborn rats over the first week of life. Two groups of newborn rats were used: fasted newborns delivered by cesarean section studied within $8 \mathrm{hr}$ after birth and suckling newborns naturally delivered. The latter were studied from 12-144 hr after birth. $F$ indicates fetal plasma values obtained before cesarean section. The results are expressed as means \pm SEM and the integer represents the number of animals. 


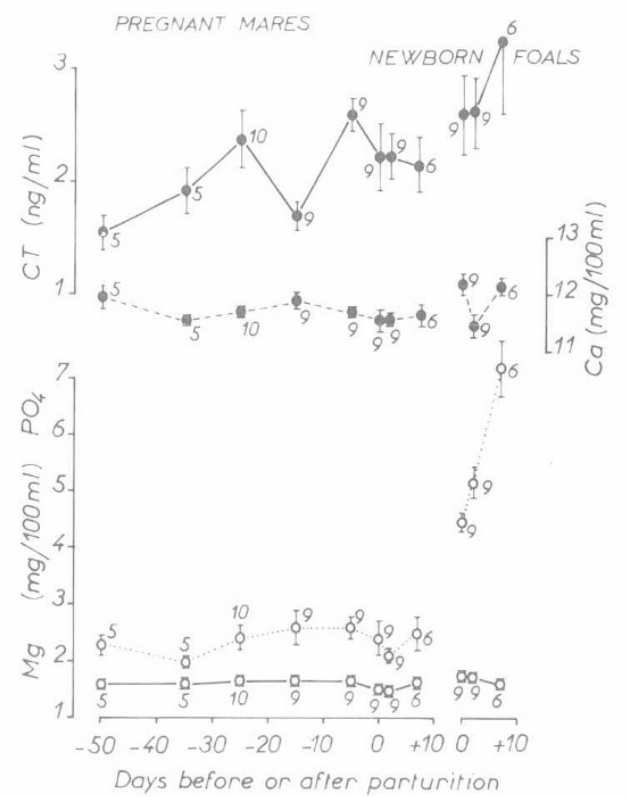

Fig. 2. Jugular venous plasma concentrations of calcium (-_ inorganic phosphorus $(\mathrm{O} \cdots \mathrm{O})$, magnesium $\left(\mathrm{O} \_\mathrm{O}\right)$, and calcitonin (-) in pregnant mares and their newborn foals. Means \pm SEM and the integer indicates the number of estimations.

sharply over the first week of life $(P<0.005)$ (Fig. 2). The plasma magnesium concentration in newborn foals did not change over the first week of life (Fig. 2); however, the plasma magnesium level in the 2-day-old newborn was greater than in the mother at the same time $(1.72 \pm 0.06$ vs. $1.47 \pm 0.05 \mathrm{mg} / 100 \mathrm{ml} ; P<0.01)$. From birth to the sixth day postpartum, the mean plasma CT levels were greater in foals than in mothers, but at each stage studied the difference was not significant. Over the first week of life the plasma CT level in newborns was not changed (Fig. 2).

\section{NEWBORN LAMBS}

From $24 \mathrm{hr}$ to 6 weeks after parturition the plasma calcium and the plasma inorganic phosphorus concentrations were greater in the lamb than in the mother (Fig. 3). A 2-fold increase in plasma inorganic phosphorus occurred between $0 \mathrm{hr}$ and 3 weeks after birth in the lamb and a small but significant increase $(0.7 \mathrm{mg} / 100$ $\mathrm{ml}$ ) was also observed in plasma calcium concentration. In ewes, the plasma calcium and the plasma inorganic phosphorus concentrations were slightly increased 6 weeks after parturition; the plasma magnesium level remained constant over the same period. The plasma magnesium concentration was found to be lower in the lamb than in the mother at birth; this small difference was still evident 3 weeks afterwards but was absent 6 weeks after parturition. A significant increase in the plasma magnesium level $(0.34$ $\mathrm{mg} / 100 \mathrm{mi}$ ) was observed in the lamb $24 \mathrm{hr}$ after birth but this level was reduced $(-0.36 \mathrm{mg} / 100 \mathrm{ml}) 1$ day later. A sharp increase in the plasma CT level was observed in ewes for the 3 weeks after parturition during lactation (Fig. 3) but values fell 3 weeks later. At birth the level of CT in the plasma was very high in the lamb $(8.10 \pm 2.05 \mathrm{ng} / \mathrm{ml}$ vs. $1.85 \pm 0.55 \mathrm{ng} / \mathrm{ml}$ in the mothers; $P<$ $0.025)$ and then decreased $4 \mathrm{hr}$ afterwards $(3.80 \mathrm{ng} / \mathrm{ml})$ but returned to its initial value $24 \mathrm{hr}$ after birth $(8.37 \mathrm{ng} / \mathrm{ml})$. Before weaning this CT level was unchanged.

\section{NEWBORN CALVES}

The plasma calcium level in newborn calves increased between 0 and 2.5 days after birth $(2.00 \mathrm{mg} / 100 \mathrm{mg})$ and then decreased significantly on day 5 (Fig. 4). The plasma inorganic phosphorus concentration was also increased after birth $(2.50 \mathrm{mg} / 100 \mathrm{ml}$ between day 0 and day 2.5; $P<0.05$ ). Detectable plasma PTH levels were measured at birth in newborn calves with values ranging from $0.80 \mathrm{ng} / \mathrm{ml}$ to $3.50 \mathrm{ng} / \mathrm{ml}$. All individual values measured in newborn calves during the first week of life were detectables (range $0.60-3.50 \mathrm{ng} / \mathrm{ml}$ ) since the assay can detect values equal or higher than $0.30 \mathrm{ng} / \mathrm{ml}$. These levels were similar to those found in mothers during the same period. There was no significant change in means of plasma PTH concentrations from newborn calves during the period studied (Fig. 4). The plasma CT level increased significantly $(P<0.05)$ between $24 \mathrm{hr}$ and $60 \mathrm{hr}$

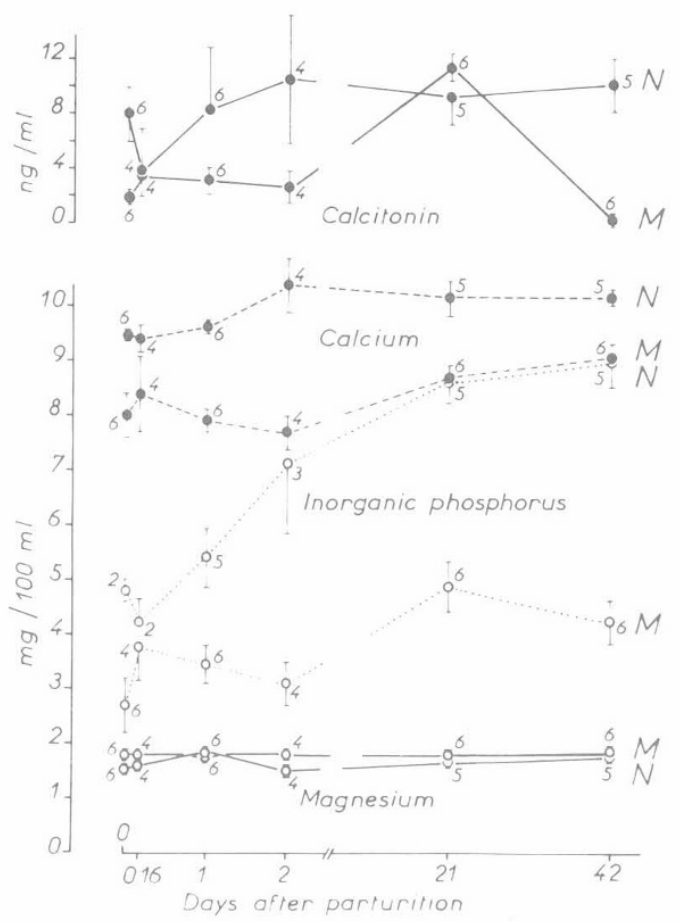

Fig. 3. Jugular venous plasma concentrations of calcium, inorganic phosphorus, magnesium, and calcitonin in ewes $(M)$, and their newborn lambs $(N)$. Means \pm SEM and the integer indicates the number of estimations.

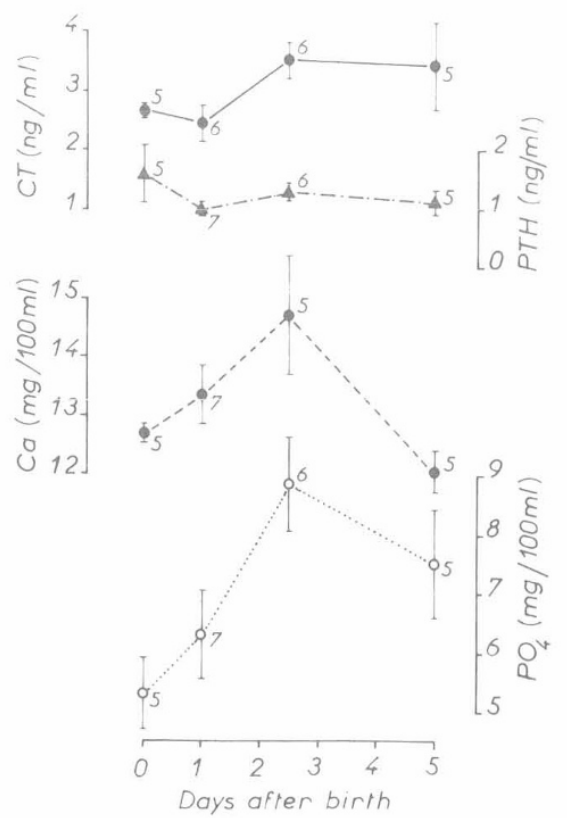

Fig. 4. Jugular venous plasma concentrations of calcium, inorganic phosphorus $\left(\mathrm{PO}_{4}\right)$, calcitonin $(\mathrm{CT})$, and parathyroid hormone $(\mathrm{PTH})$ in newborn calves. Means \pm SEM and the integer indicates the number of estimations. 
after birth (Fig. 4). PTH hormonal patterns were very different from one calf to another. In one animal plasma PTH level decreased $11 \mathrm{hr}$ after birth from $3.50 \mathrm{ng} / \mathrm{ml}$ to $1.30 \mathrm{ng} / \mathrm{ml}$ before the increase in plasma calcium concentration and remained low during the first week after birth. In a second calf the plasma PTH level which was $1.50 \mathrm{ng} / \mathrm{ml}$ at birth decreased to $0.90 \mathrm{ng} / \mathrm{ml}$ within $6 \mathrm{hr}$ and then increased to $1.90 \mathrm{ng} / \mathrm{ml} 48 \mathrm{hr}$ after birth in spite of an increase in plasma calcium concentration. In newborn calves studied there was no negative relation between plasma calcium and PTH concentrations. It may be possible that plasma PTH levels were related to plasma magnesium concentrations, but unfortunately magnesium levels were not measured. Better relations were observed in individual animals between plasma calcium and CT concentrations so that an increase in plasma calcium was associated with an increase in plasma CT.

\section{DISCUSSION}

In general plasma CT levels were greater in newborns than in their mothers, such as in newborn lambs and foals, but the mean concentrations were never related to plasma calcium or to plasma inorganic phosphorus. In calves, newborn and mother plasma CT values were not different since these cows developed at parturition a fall in plasma calcium and inorganic phosphorus concentrations associated with a rise in plasma CT which were already described elsewhere $(22,23)$. High CT levels were also described in human newborns $(8,31)$. Factors which control the high plasma CT level in the newborn are poorly understood. It has been shown that calcium given orally ( $10 \mathrm{mg} \mathrm{Ca} / \mathrm{kg}$ body weight) in the 1 -hr-old fasted newborn lamb did not change the plasma calcium concentration but increased plasma CT I hr later (6). However, gastrin, a well known potent CT secretagogue in adults, which was found active after weaning in lambs (3), remained ineffective before weaning at a dose of $2 \mu \mathrm{g} / \mathrm{kg}$ body weight in the 1-hr-old fasted newborn lamb (6). The rise in plasma CT concentration associated with a drop in plasma calcium and inorganic $\mathrm{P}$ concentrations, 60 and $90 \mathrm{~min}$ after cholecystokinin-pancreozymin (CCK-PZ) injection in the 20-min-old fasted newborn lamb demonstrated an increase in CT release (4). In suckling newborn animals, the release of CCK-PZ might be stimulated as in adults (45) by a lipid-rich diet such as colostrum and milk. Thus the duodenal hormone CCK-PZ seems able to play the main role in the regulation of postprandial nutrient absorption by increasing CT release in the newborn animals (24).

The finding reported in this paper of detectable levels of PTH (similar to those found in adults) in newborn calves soon after birth indicated that parathyroid function in this species was not depressed. The parathyroid status in calves and rhesus monkey during the early postnatal period seems to be closed since the latter have been shown to exhibit detectable levels of PTH within $24 \mathrm{hr}$ after birth (17). In contrast, in the majority of normal human newborns, the serum immunoreactive PTH levels were undetectable or low during the first $48 \mathrm{hr}$ of life (14).

In light of these results it is useful to briefly review previously published works, in which attempts were made by a variety of means to assess parathyroid function during fetal life in mammals. Several reports based on histologic observations have claimed the functional activity of the fetal parathyroid glands in humans (2, 9 . $37)$ and in rats $(2,30,33,42)$. In vitro studies, lacking the fetal "milieu interieur" which is quite different from that found in adults, strongly suggest that early during embryonic life and throughout fetal life secretory activity is present in human, sheep. and guinea pig parathyroid glands $(29,41)$, as indicated by the ability of the glands to induce bone resorption. Further evidence for the presence of parathyroid hormone in the fetus is that a fall in plasma calcium occurs in the rat fetus after thyroparathyroidectomy or the injection of anti-bovine PTH serum $(19,38,39)$ which is corrected by parathormone (PTE) injection (26). Furthermore, thyroparathyroidectomy in rat fetuses delayed the recovery from EDTA-induced hypocalcemia (20). It has also been shown that thyroparathyroidectomy in rat fetuses induced a decrease in the plasma magnesium level (21). More direct evidence for active fetal parathyroid function was obtained by two groups: Smith et al. (43) and Care et al. (10), who demonstrated increased levels of plasma immunoreactive PTH in sheep fetuses at the end of gestation in response to EDTA-induced hypocalcemia. In this regard, the work of Fleischman et al. (17) in rhesus monkey is in contrast, since in this species the fetus does not respond to EDTA infusion by an increase in the plasma PTH level.

It is well known that in mammalian fetuses, the plasma calcium level at the end of gestation is higher than in the mother. Higher ult rafiltrable and ionized plasma calcium concentrations have been observed in the fetus than in the mother $(7,14,15,40)$. The findings of undetectable or low immunoreactive plasma PTH levels in sheep $(10,43)$ and rhesus monkey fetuses (17) as well as in cord blood of human newborns (14) strongly suggest that in these three species parathyroid hormone secretion is turned off; but the work in rhesus monkey indicates that the high plasma calcium level is not the (sole) factor involved in this suppression. By contrast, in rat fetuses, even fetal plasma calcium depends primarily on the rate of calcium transfer across the placenta, several lines of evidence suggest that parathyroid glands also contribute to the maintenance of fetal plasma calcium.

To summarize, it can be concluded that the parathyroid status in the neonatal period is specific to the species studied and that it will be hazardous to generalize the results obtained in one species to the different species. Furthermore, the cause of the inhibition of fetal parathyroid hormone secretion at the end of gestation in some species remains obscure.

From the present findings and in the different species studied so far, the postnatal increase in plasma inorganic phosphorus is a general pattern. This elevation was attributed by some authors to a low renal excretion of phosphates during the postnatal period, or it may be the result of a transient hypoparathyroidism, and/or to the end-organ unresponsiveness to PTH. In sheep fetuses near term it is well known that the tubular reabsorption of phosphate (TRP) is high, but parathyroid extract injection decreases the TRP and increases the phosphate clearance $(1,44)$. Moreover, EDTA infusion in sheep fetuses, which increases the plasma immunoreactive PTH level, induced a stimulation of phosphate clearance (43). These results indicate that renal cortex adenyl cyclase responds to PTH in utero in sheep fetuses near term. In vitro experiments have shown that adenyl cyclase of renal cortex homogenates from 27 days to term rabbit fetuses is stimulated to the same extent as adult extracts by PTH (36). In rats, the basal renal adenyl cyclase activity was highest on the third day after birth and then declined to very low levels from the fifth day; parathyroid hormone produced a marked stimulation of the homogenate adenyl cyclase activity from 1 to 5 days after birth (28).

It is well known that in 1-day-old human newborns phosphate excretion and clearance are low but rise significantly on the third day (12). A 50-fold increase in phosphate excretion and a 30-40-fold increase in phosphate clearance was observed by Linarelli (35). The glomerular filtration rate is known to increase between days 1 and 3 and this rise could mainly explain the rise in phosphaturia since TRP slightly decreases during this period in the human neonate. Thus, TR P cannot explain the significant rise in plasma inorganic phosphorus on the third day (14). The increase in phosphate excretion and clearance and the decrease in TRP induced by PTE injection in human newborns is higher on the third day than on the first day $(12,35)$. It has also been demonstrated that basal and PTE-stimulated urinary cyclic AMP is higher on the third day than on the first day (35). This indicates that renal sensitivity to PTH increases progressively after birth in human neonates. The increase in parathyroid activity observed in normal newborns after $48 \mathrm{hr}$ of life (14) is consistent with the increase in phosphate excretion and urinary cyclic AMP reported by Linarelli (35).

The association in the human newborn of hypocalcemia (shifts in total and ionized calcium) and hyperphosphatemia have sug- 
gested the existence of a transient hypoparathyroidism; this concept had been developed by many authors. This was substantiated by the observation of low or undetectable plasma PTH levels in human newborns (14). Concomitantly there is a relative end-organ unresponsiveness to $\mathrm{PTH}$.

Indeed, there is considerable species variation in the maturity of the renal cortex adenyl cyclase system at birth, even the postnatal increase in plasma inorganic phosphorus always occurred. Thus, end-organ unresponsiveness or immaturity of the renal receptor cannot explain the rise in plasma inorganic phosphorus concentration after birth.

The spectrum of transient hypoparathyroidism is observed only in some species (human and perhaps horse) since neonatal hypocalcemia is very uncommon in animals. In horses the postnatal decrease in calcium was very small and in the absence of estimations of plasma PTH levels, the existence of a neonatal hypoparathyroidism remains speculative. In newborn lambs and newborn calves the postnatal increase in plasma inorganic phosphorus was not associated with a decrease in plasma calcium; whereas, in rats, the developmental changes of these two parameters were parallel after birth. Moreover, in newborn calves the plasma PTH levels were similar to those found in adults.

It has been shown that $\mathrm{CT}$ increases in vitro the PTH secretion rate from porcine parathyroid glands under conditions in which secretory activity of the slices was inhibited (16). Since in some species parathyroid secretion is depressed at birth, a postnatal increase in CT would be a stimulus increasing the PTH level in the days after birth. In fact, Bergman et al. (8) have observed in human newborns an increase in plasma CT level after birth, the highest level occurring $24-48 \mathrm{hr}$ after birth. In this regard it is pertinent to note that plasma PTH levels increased after $48 \mathrm{hr}$ of age (14). In newborn calves it was not the rule since plasma PTH levels did not change from 0 to 5 days postpartum in spite of an increase in the plasma CT level at 2.5 days which may be better related to the increment in plasma calcium concentration.

\section{SUMMARY}

The postnatal evolution of plasma calcium, magnesium and inorganic phosphorus concentrations was analyzed in four species: in a rodent (rats), in foals, and in ruminants (lambs and calves) over the first week of life. In newborn rats a marked decrease in plasma calcium and inorganic phosphorus concentrations was observed within $2 \mathrm{hr}$ after delivery and then both increased between $12 \mathrm{hr}$ and $36 \mathrm{hr}$ after birth. In newborn foals a slight hypocalcemia occurred within $48 \mathrm{hr}$ after birth. In contrast, newborn lambs and calves did not show changes in plasma calcium levels. However, in the four species studied, the plasma inorganic phosphorus concentration was increased in the days after birth; and plasma magnesium levels remained relatively constant during the same time. In general, plasma CT concentrations (measured by radioimmunoassay using a porcine system cross-reacting with ovine, bovine, and equine CT) in newborn ruminants and foals were high in comparison with those found in their mothers, but these leveis appeared related neither to plasma calcium nor to plasma phosphates. Plasma parathyroid hormone concentrations were found to be detectable at birth in newborn calves, the levels being similar to those found in their mothers. These results were discussed in light of the well known early neonatal hypocalcemia occurring in normal human newborns.

\section{REFERENCES AND NOTES}

1. Alexander, D. P., and Nixon, D. A.: Effect of parathyroid extract in foetal sheep. Biol. Neonate, 14: 117 (1969)

2. Altenahr, E., and Wohler, J.: Ultrastructural study on the functional differenciation of parathyroid glands during the embryonal, fetal and neonatal period. Verh. Dtsch. Ges. Pathol., 55: 160 (1971).

3. Barlet, J. P.: Effet d'une perfusion intraveineuse de gastrine ou d'une excitation vagale sur la calcémie et la phosphatémie du mouton. C. R. Hebd. Séances Acad. Sci. (Paris) D, 274: 2220 (1972).

4. Barlet, J. P., and Garel, J. M.: The effect of an intraveinous injection of cholecystokinin-pancreozymin on plasma calcium and calcitonin levels in newborn lambs. J. Endocrinol. (In press.)

5. Barlet, J. P., Michel, M. C., Larvor, P., and Theriez, M.: Calcémie, phosphatémie, magnésémie et glycémies comparées de la mère et du nouveau-né chez les ruminants domestiques (vache, chèvre, brebis). Ann. Biol. Anim. Biochim. Biophys., 11: 415 (1971).

6. Barlet, J. P., Michel, M. C., Theriez, M., Savajol, H., and Garel, J. M.: Calcitoninémie et effets métaboliques de la calcitonine chez l'agneau nouveauné. J. Physiol. (Paris), 68: 519 (1974).

7. Bawden, J. W., Wolkoff, A. S., and Flowers, C. E.: Maternal-fetal blood calcium relationships in sheep. Obstet. Gynecol., 25: 548 (1965).

8. Bergman, L., Kjellmer, I., and Selstam, U.: Calcitonin and parathyroid hormone-relation to early neonatal hypocalcemia in infants of diabetic mothers. Biol. Neonate, 24: 1 (1974).

9. Boyd, J. D.: Development of thyroid and parathyroid glands and the thymus. Ann. R. Coll. Surg. Engl., 7: 455 (1950).

10. Care, A. D., Pickard, D. W., Garel, J. M., Barlet, J. P., Tomlinson, S, and O'Riordan, J. L. H.: Autonomy of calcium homeostasis in the sheep foetus. Horm. Metab. Res., 7: 103 (1975).

11. Chen, P. S., Toribara, T. Y., and Warner, H.: Microdetermination of phosphorus. Anal. Chem., 28: 1756 (1956).

12. Conelly, J. P., Crawford, J. D., and Watson, J.: Studies of neonatal hyperphosphatemia. Pediatrics, 30: 425 (1962).

13. Craig, W. S., and Buchanan, M. F. G.: Hypocalcaemic tetany developing within 36 hours of birth. Arch. Dis. Childhood, 33: 505 (1958)

14. David, L., and Anast, C. S.: Calcium metabolism in newborn infants. J. Clin. Invest., 54: 287 (1974).

15. Delivoria-Papadopoulos, M., Battaglia, F. C., Bruns, P. D., and Meschia, G. Total, protein-bound, and ultrafiltrable calcium in maternal and fetal plasmas. Amer. J. Physiol., 213: 363 (1967),

16. Fisher, J. A., Oldham, S. B., Sizemore, G. W., and Arnaud, C. D.: Calcitonin stimulation of parathyroid hormone secretion in vitro. Horm. Metab. Res., 3: 223 (1971).

17. Fleischman, A. R., Lerman, S., Oakes, G. K., Epstein, M. F., Chez, R. A., and Mintz. D. H.: Perinatal primate parathyroid hormone metabolism. Biol. Neonate, 27: 40 (1975).

18. Garel, J. M.: Action hypocalcémiante et hypophosphaté miante de la thyrocalcitonine chez le rat avant et après la naissance. C. R. Hebd. Séances Acad. Sci. (Paris) D, 268: 1525 (1969).

19. Garel, J. M.: Effet de l'injection d'un sérum "anti-parathormone". chez le foetus de rat. C. R. Hebd. Séances Acad. Sci. (Paris) D, 27l: 2364 (1970).

20. Garel, J. M.: Assessment of fetal rat parathyroid gland activity during hypocalcemia induced by EDTA. Biol. Neonate, 27: 115 (1975).

21. Garel, J. M., and Barlet, J. P.: The effects of calcitonin and parathormone on plasma magnesium levels before and after birth in the rat. J. Endocrinol., 61: 1 (1974).

22. Garel, J. M., and Barlet, J. P.: Plasma immunoreactive calcitonin and parathyroid hormone levels in parturient cows. J. Endocrinol., 66: 299 (1975).

23. Garel, J. M., and Barlet, J. P.: A radioimmunoassay for bovine parathyroid hormone. J. Physiol. (Paris) (In press.)

24. Garel, J. M., Barlet, J. P., and Kervran, A.: Metabolic effects of calcitonin in newborns. Amer. J. Physiol., 229: 669 (1975).

25. Garel, J. M., Care, A. D., and Barlet, J. P.: A radioimmunoassay for ovine calcitonin: An evaluation of calcitonin secretion during gestation, lactation and foetal life. J. Endocrinol., 62: 497 (1974).

26. Garel, J. M., Pic, P., and Jost, A.: Action de la parathormone chez le foetus de rat. Ann. Endocrinol., 32: 253 (1971)

27. Garel, J. M., Savajol, H., and Barlet, J. P.: Plasma immunoreactive calcitonin levels in pregnant ewes and their lambs. Biol. Neonate (In press.)

28. Gengler, W. M., and Forte, L. R.: Neonatal development of rat kidney adenyl cyclase and phosphodiesterase. Biochim. Biophys. Acta, 279: 367 (1972).

29. Graham, R. W., and Scothorne, R. J.: The onset of functional capacity in fetal guinea-pig parathyroid glands. Quart. J. Exp. Physiol., 56: 41 (1971).

30. Hansson, C. G., and Svalander, C.: Aminopeptidase activity in foetal rat parathyroids and its inhibition by vitamin D-induced hypercalcaemia in the mother rat. Acta Endocrinol., 55: 256 (1967).

31. Hesch, R. D., Woodhead, S., Huefner, M., and Woif, H.: Gastrointestinal stimulation of calcitonin in adults and newborns. Horm. Metab. Res., 5: 235 (1973).

32. Hunter, W. M., and Greenwood, F. C.: Preparation of ${ }^{131}$ I-labelled human growth hormone of high specific activity. Nature (London), 194: 495 (1962).

33. Jost, A., Pic, P., Maniey, J., and Legrand, C.: Action du propylthiouracile donné a la ratte gestante sur les parathyroides et sur la calcémie des foetus: Remarques sur la physiologie des parathyroides. Acta Endocrinol., 43: 618 (1963).

34. Lehr, D., and Krukowski, M.: Protection by pregnancy against the sequelae of acute hyperparathyroidism. Naunyn Schmiedeberg's Arch. Exp. Pathol. Pharmakol., 242: 143 (1961).

35. Linarelli, L. G.: Newborn urinary cyclic AMP and developmental renal responsiveness to parathyroid hormone. Pediatrics, 50: 14 (1972).

36. Linarelli, L. G., Bobik, J., and Bobik, C.: The effect of parathyroid hormone on rabbit renal cortex adenyl-cyclase during development. Pediat. Res., 7: 878 (1973).

37. Norris, E. H.: Anatomical evidence of prenatal function of the human parathyroid glands. Anat. Rec., 96: 129 (1946)

38. Pic, P.: Rôle des parathyroïdes foetales dans la régulation de la calcémie et de la phosphatémie du foetus de rat. Ann. Endocrinol., 34: 621 (1973). 
39. Pic, P., Maniey, J., and Jost, A.: Facteurs endocriniens réglant la calcémie foetale: Indications sue le rôle des parathyroïdes C. R. Soc. Biol., 159: 1274 (1965).

40. Radde, I. C., Parkinson, D. K., and Hoffken, B.: Ionized calcium in the healthy and diseased neonate. Proc. XIII Inter. Congr. Pediat.: 363 (1971).

41. Scothorne, R. J.: Functional capacity of fetal parathyroid glands with reference to their clinical use as homografts. Ann. N.Y. Acad. Sci., 120: 669 (1964).

42. Sinclair, J. G.: Fetal rat parathyroids as affected by changes in maternal serum calcium and phosphorus through parathyroidectomy and dietary control. J. Nutr., 23: 141 (1942).

43. Smith, F. G., Alexander, D. P., Buckle, R. M., Britton, H. G., and Nixon, D. A.: Parathyroid hormone in foetal and adult sheep: The effect of hypocalcemia. J. Endocrinol., 53: 339 (1972).
44. Smith, F. G., Tinglof, B. O., Meuli, J., and Borden, M. Fetal response to parathyroid hormone in sheep. J. Appl. Physiol., 27: 276 (1969).

45. Young, J. D., Lazarus, L., Chisholm, D. J., and Atkinson, F. F. U. Radioimmunoassay of pancreozymin cholecystokinin in human serum. J. Nucl. Med., 10: 743 (1969).

46. Laboratoires Choay, Paris, France.

47. This work was supported by the Centre National de la Recherche Scientifique (ATP A655 1310) and the Délégation Générale à la Recherche Scientifique et Technique (Contract 74-7-0020).

48. Requests for reprints should be addressed to: J. M. Garel, M.D., Laboratoire de Physiologie du Développement, Université Pierre et Marie Curie, 9 quai Saint-Bernard, 75230 Paris cedex 05 (France).

49. Accepted for publication March 10, 1976

\title{
Studies on the Distribution of Cholinesterases: Activity in the Human and Dog Heart
}

\author{
SACHCHIDA N. SINHA, ${ }^{(36)}$ STEVEN KERESZTES-NAGY, AND ALLEN FRANKFATER \\ Departments of Pediatrics and Biochemistry, Loyola University Stritch School of Medicine, Maywood, Illinois, USA
}

\section{Extract}

The distribution and postnatal variation of cholinesterase $(\mathrm{ChE})$ activity were studied in 25 human and 25 dog hearts. The observed distribution pattern is remarkably constant. In dog hearts, the pattern is as follows: sinus node $(\mathrm{SN})>$ left atrium $(\mathrm{LA})>$ right atrium $($ RA $)>$ right ventricle $(R V) \simeq$ left ventricle $(L V)$. The average acetylcholinesterase (AcChE) activities as expressed in international units per $\mathrm{g}$ wet tissue are: $1.66(\mathrm{SN}), 1.14(\mathrm{LA}), 0.70$ (RA), 0.22 ( RV), and 0.21 ( $\mathrm{LV})$. In human hearts, the AcChE distribution follows the pattern of $\mathrm{RA}>\mathrm{LA}>\mathrm{RV} \simeq \mathrm{LV}$ with corresponding average activities of $1.70,1.38,0.51$, and $0.44 \mathrm{IU}$.

The postnatal variation of $\mathrm{ChE}$ activity is most pronounced in the $\mathrm{RA}$ of the heart in both species. The average AcChE activity in the $\mathrm{RA}$ of the newborn puppies is $0.51 \mathrm{IU}$ as compared with $2.27 \mathrm{IU}$ in newborn infants. In the adult heart, however, the average atrial AcChE activity is nearly identical (1.02 IU) in both species.

An additional difference is the large $(34-64 \%)$ contribution of butyrylcholinesterase $(\mathrm{BuChE})$ to the total activity in dog hearts whereas the contribution of $\mathrm{BuChE}$ is small $(7-15 \%)$ in human hearts.

\section{Speculation}

The relative $\mathrm{AcChE}$ activities and the distribution of this enzyme seem to follow the vagal innervation of the various parts of the heart. The low enzyme activities observed in the newborn puppies correlate well with histochemical and functional studies indicating incomplete development of the vagal innervation of the heart in this species at birth. In newborn babies, however, the vagal innervation of the heart is reportedly fully developed and the heart is markedly sensitive to vagal stimuli. The high $\mathrm{AcChE}$ activity present in the human heart at birth is compatible with these observations. Moreover, a decline of $\mathrm{AcChE}$ activity with age may represent a postnatal maturation process of the parasympathetic system of the heart which has not yet been appreciated.

Cholinesterases, the enzymes which inactivate acetylcholine, appear in the myocardium early during fetal development and precede the innervation of the heart (17). Although the ontogenesis of these enzymes has been well reviewed and it has been shown that full ChE activity in the heart is present at birth, postnatal changes in the actual enzyme levels per se have not been adequately investigated. Recent studies indicate that autonomic innervation of the cardiovascular system is far from complete at birth and, depending upon the species, maturation of the innervation continues in the postnatal period $(2,16,25)$. In an attempt to investigate the development of the autonomic control of the heart and its clinical implications, we decided to analyze the cholinesterase levels as related to age in different parts of the heart in humans and dogs. In this presentation, we wish to report significant speciesand age-related differences in the distribution of the cholinesterases in the heart.

\section{MATERIALS AND METHODS}

Myocardial tissue from 25 dog hearts and 25 human hearts form the subject material of this study. Twenty-five dogs ranged in age from I day to adult. Most of the animals were used for open-chest physiologic study; some littermates in the first 3 weeks of life were killed specifically to obtain myocardial tissue for chemical analysis. Human heart tissues were obtained from autopsied material at the Cook County Coroner's morgue and they ranged in age from 1 week to adult. There were 21 infants: 15 had died of sudden infant death syndrome (SIDS) and 6 of trauma. Four adults who died of trauma were also included. Specimens were obtained from right and left atrial appendages, and from the anterior wall of the right 